\title{
Post-Cryo Survival of Rat Testicular Interstitial Cells in Hydroxyethyl Starch-Based Media
}

\begin{abstract}
Реферат: Розробка кріозахисних середовищ, які не містять сироватку або інші ксеногенні компоненти, необхідна для безпечного використання кріоконсервованого матеріалу сім'яників із метою трансплантації. Було показано, що розчини, які містили 10\% фетальної телячої сироватки (ФТС) або 5 мг/мл бичачого сироваткового альбуміну (БСА), значно не збільшували загальну збереженість клітин інтерстицію (КІ) після кріоконсервування, але підвищували метаболічну активність КІ та збереженість стероїд-продукуючих клітин (ГСД+-клітин). Застосування гідроксиетил крохмалю (ГЕК) у концентрації 50 та 100 мг/мл у складі кріозахисних розчинів на основі ДМСО дозволило підвищити показники загальної збереженості КІ та збереженості ГСД+-клітин на відміну від середовищ, які містили БСА або ФТС. Кріозахисні середовища з ГЕК дозволяють знизити концентрацію диметилсульфоксиду (ДМСО) у розчині з 1,4 до 0,7 М та зберегти кількість і метаболічну активність КІ. Таким чином, розробка кріозахисних розчинів, які містять ДМСО у комбінації з ГЕК, може бути основою для створення розчинів, до яких не входять ксеногенні компоненти і, в свою чергу, може спростити процедуру впровадження кріоконсервованого матеріалу в практичну медицину.

Ключові слова: кріоконсервування, кріопротектори, клітини Лейдига, гідроксиетил крохмаль.

Abstract: The development of cryoprotective serum- free or xeno-free media, is required for safe use of cryopreserved testicular material for transplantation. In this study, the solutions containing $10 \%$ fetal bovine serum (FBS) or $5 \mathrm{mg} / \mathrm{ml}$ bovine serum albumin (BSA) did not significantly enhance the general survival of interstitial cells (ICs) after cryopreservation, but increase their metabolic activity and steroid producing cell (HSD+-cells) survival. The use of 50 and $100 \mathrm{mg} / \mathrm{ml}$ hydroxyethyl starch (HES) in DMSO-based cryoprotective solutions instead of BSA or FBS enabled the improvement of the IC general survival and the survival of $\mathrm{HSD}^{+}$-cells. The use of HES supplemented media allowed to decrease the dimethyl sulfoxide (DMSO) concentration from 1.4 to $0.7 \mathrm{M}$ and to preserve the amount and metabolic activity of ICs. Thus, designing cryoprotective media containing DMSO and HES can facilitate the formulation of serum-free solutions for cryopreservation that in turn paves a way for implementation of the use of cryopreserved material for practical medicine.
\end{abstract}

Key words: cryopreservation, cryoprotective agents, Leydig cells, hydroxyethyl starch.

Клітинам інтерстицію (КІ) сім'яника належить значна роль у забезпеченні репродуктивної функції ссавців, оскільки вони секретують чоловічі статеві гормони. Ці властивості визначають цінність КІ як біологічного матеріалу, який може бути застосовано у регенеративній медицині $[1,10]$.

Практичне використання КІ потребує забезпечення їх достатнього резерву. У зв'язку з цим розробка і удосконалення методів довгострокового зберігання КІ $\epsilon$ актуальними. Традиційно для кріоконсервування суспензії цих клітин використовують проникний кріопротектор ДМСО у концентрації 0,7-2,1 M [4,33], а також сироватку або сироватковий альбумін. На думку Y. Liu

Відділ кріоендокринології, Інститут проблем кріобіології і кріомедицини НАН України
Testicular interstitial cells (ICs) have a key role in ensuring the reproductive function in mammals by producing male sex hormones. These properties stipulate the value of ICs for a potential application in regenerative medicine $[8,18]$.

The implementation of ICs into practice necessitates establishing their sufficient stocks. In this context, the development and improvement of the methods for long-term storage of ICs is of high importance. The penetrating cryoprotectant DMSO at $0.7-2.1 \mathrm{M}$ concentration $[2,33]$, as well as serum or serum albumin are commonly used for cryopreervation of cell suspensions. Y. Liuta et al. [23] have suggested that serum 'stabilizes' membranes, prevents their osmotic damage, and protects cells against

Department of Cryoendocrinology, Institute for Problems of Cryobiology and Cryomedicine of the National Academy of Sciences of Ukraine, Kharkiv, Ukraine

Address for correspondence:

23, Pereyaslavska str., Kharkiv, Ukraine 61016

tel.:+380 57373 7435, fax: +380 573735952

e-mail: aleksandr.pakhomov2017@gmail.com

Received March, 13, 2020

Accepted February, 08, 2021 
та співав. [25] сироватка сприяє «стабілізації» мембран, попереджує їх осмотичне пошкодження, захищає клітини від дії вільних радикалів. Сироватка може містити різні патогенні організми, які призводять до зоонозних захворювань, або фактори, які викликають пріонну хворобу, що має нейродегенеративні наслідки [14, 36]. Використання контамінованої сироватки спричиняло виникнення хвороби Крейцфельдта-Якоба та гепатиту [7, 16, 22, 37]. Слід зазначити, що стерилізація донорських сироваткових білків і людського або бичачого сироваткового альбуміну не гарантує елімінацію усіх патогенів. Окрім того, у комерційних ембріональних культуральних середовищах було знайдено різноманітні досі невідомі потенційно небезпечні білкові фактори [8]. Використання аутологічних сироватки або альбуміну в кріозахисному розчині не вирішує проблему, оскільки потребує дооперативних маніпуляцій, додаткових коштів і може бути нездійсненим за деяких умов (важкий стан пацієнта, наявність інфекційних хвороб або ургентність). Сироватка та іiі похідні призводять до варіювання складу розчинів у процесі виготовлення різних партій кріоконсерванта [31], що може позначитися на їх якості. Таким чином, для кріоконсервування КІ сім'яників необхідно розробити ефективний i біобезпечний кріоконсервант. Для цього важливо виключити ксеногенні компоненти (сироватку та ii похідні) та знизити концентрацію ДМСО, який має потенційну токсичну дію $[5,13]$. Перспективним рішенням цієї проблеми є використання у складі кріозахисного середовища високомолекулярних сполук і сахаридів [2, 26, 30]. Однією з таких сполук є гідроксиетил крохмаль (ГЕК), низьку токсичність якого було показано на різних біологічних об'єктах $[11,12,15]$.

Мета роботи - дослідження захисної дії кріоконсервантів, які містять ДМСО у комбінації 3 ГЕК під час кріоконсервування клітин інтерстицію сім' яника щурів.

\section{Матеріали та методи}

Експерименти проводили відповідно до Закону України «Про захист тварин від жорстокого поводження» (№3447-IV від 21.02.2006р.) із дотриманням вимог комітету 3 біоетики Інституту проблем кріобіології і кріомедицини НАН України, узгоджених із положенням «Свропейської конвенції 3 захисту хребетних тварин, які використовуютсья в експериментальних та інших наукових цілях» (Страсбург, 1986).

Донорами КІ сім'яника були дорослі щури віком 5-6 місяців. Сім'яники діставали з черев- free radical effect. However, serum may include different pathogenic organisms, which can cause zoonotic or factors inducing prion diseases, having neurodegenerative consequences $[12,36]$. The use of contaminated serum led to the CreutzfeldtJakob disease and hepatitis [5, 14, 21, 37]. It is noteworthy, that sterilization of donor serum proteins and human or bovine serum albumin can not ensure the elimination of all pathogens. Furthermore, different unknown potentially dangerous protein factors were found in commercial embryo culture media [6]. This problem can be hardly solved by introducing autologous serum or albumin in cryoprotective solution because some preoperative manipulations and additional funds are required. Other conditions such as poor health state of patient, presence of infectious diseases or urgency can make it impossible either. The use of serum and its derivatives may alter the solution composition when manufacturing different batches of cryopreservative agents [31], thus affecting their quality. Therefore, the designing of an efficient and biosafe cryopreservative is vital for testicular ICs cryopreservation. For this purpose, it is necessary to exclude xenogenic components (serum and its derivatives) and reduce DMSO concentration, which has a potential toxic effect $[3,11]$. The use of high-molecular compounds and saccharides in cryoprotective media is a promising approach $[28,25,30]$. Hydroxyethyl starch (HES), the low toxicity of which has been shown in various biological objects, is one of such compounds [9, $10,13]$.

The research was aimed to study a cryoprotective effect of cryopreservatives, containing DMSO and supplemneted with HES during cryopreservation of rat testicular interstitial cells (ICs).

\section{Materials and methods}

Experiments were performed in accordance with the Law of Ukraine 'On the Protection of Animals Against Cruelty' (№3447-IV of February, 21 , 2006) in compliance with the requirements of the Bioethics Committee of the Institute for Problems of Cryobiology and Cryomedicine of the NAS of Ukraine, agreed to the statements of the European Convention for the Protection of Vertebrate Animals Used for Experimental and Other Scientific Purposes (Strasbourg, 1986).

Testicular ICs were obtained from adult 56-month-old donor rats. Testes were taken from abdo minal cavity, their tunica albuginea and blood vessels were removed. The testis content was placed into $15 \mathrm{ml}$ centrifuge tubes containing $4 \mathrm{ml}$ of enzyme solution per testis. The enzyme 
ної порожнини, видаляли їх білкову оболонку та кровоносні судини. Вміст сім'яників поміщали в центрифужні пробірки об'ємом 15 мл, які мали ферментний розчин із розрахунку 4 мл на кожний сім'яник. Ферментний розчин містив 0,2 мг/мл колагенази типу I («Sigma-Aldrich», США) i 0,1 мг/ мл ДНКази («Sigma-Aldrich») у середовищі Ham’s/ F12 («РАА», Австрія). Сім’яники витримували на водяній бані за температури $34^{\circ} \mathrm{C}$ протягом 10 хв. Після інкубування у кожну пробірку додавали 10 мл середовища Ham's/F12, сім'яні канальці видаляли за допомогою фільтрації через подвійну нейлонову сітку $з$ діаметром пор близько 100 мкм. Фільтрати, які містили клітини інтерстицію, центрифугували при $325 \mathrm{~g}$ протягом 3 хв за кімнатної температури. Супернатант видаляли, а осад клітин ресуспендували у 10 мл Ham's/F12 з 10 MO/мл пеніциліну та 100 мкг/мл стрептоміцину («Корпорація Артеріум», Україна). Процедуру седиментації повторювали двічі. Отриману суспензію клітин використовували у подальшій роботі.

Для кріоконсервування застосовували кріоконтейнери («Nunc», Данія) об’ємом 1,8 мл. Об’єм клітинної суспензії складав 1 мл, кількість клітин у кожному зразку $-5 \times 10^{6}$. У якості кріозахисних сполук використовували ДМСО, ГЕК (м.м. 200000 Да), фетальну телячу сироватку (ФТС) («Biowest», Франція), бичачий сироватковий альбумін (БСА) («Sigma-Aldrich», США), Для приготування кріозахисних розчинів застосовували середовище Наm's/F12.

Склад досліджених кріозахисних середовищ:

1 - середовище Нam's/F12, яке позначено як розчин без домішок, але 3 додаванням $0 ; 0,7 ; 1,4$; 2,1; 2,8 М ДМСО;

2 - середовище Нam's/F12 із 10\% ФТС та додаванням 0; 0,7; 1,4; 2,1; 2,8 М ДМСО;

3 - середовище Ham's/F12 iз 5 мг/мл БСА та додаванням $0 ; 0,7 ; 1,4 ; 2,1 ; 2,8$ М ДМСО;

4 - середовище Ham's/F12 із 50 мг/мл ГЕК та додаванням $0 ; 0,7 ; 1,4 ; 2,1 ; 2,8$ М ДМСО;

5 - середовище Нam's/F12 iз 100 мг/мл ГЕК та додаванням $0 ; 0,7 ; 1,4 ; 2,1 ; 2,8$ М ДМСО.

Охолодження зразків здійснювали за допомогою програмного охолоджувача «3П-10» (Дослідне виробництво при ІПКіК НАН України) до $-80^{\circ} \mathrm{C}$ зі швидкістю $1^{\circ} \mathrm{C} /$ хв. Після чого їх витримували за температури $-80^{\circ} \mathrm{C}$ протягом 15 хв і занурювали у рідкий азот. Зразки відігрівали на водяній бані при $37^{\circ} \mathrm{C}$ до зникнення кристалічної фази.

Розморожені клітинні суспензії відмивали від кріозахисного розчину шляхом його поступового розведення середовищем Наm's/F12. Після роз- solution included $0.2 \mathrm{mg} / \mathrm{ml}$ collagenase type I (Sigma-Aldrich, USA) and $0.1 \mathrm{mg} / \mathrm{ml}$ DNase (Sigma-Aldrich) in Ham's / F12 medium (PAA, Austria). Testes were incubated in a water bath at $34^{\circ} \mathrm{C}$ for $10 \mathrm{~min}$. After incubation, each tube was supplemented with $10 \mathrm{ml}$ of Ham's / F12 medium. Seminiferous tubules were removed by filtration through a double nylon mesh of about $100 \mu \mathrm{m}$ pore diameter. Filtrates containing interstitial cells were centrifuged at $325 \mathrm{~g}$ for $3 \mathrm{~min}$ at room temperature. The supernatant was removed and the cell pellet was resuspended in $10 \mathrm{ml}$ Ham's / F12 with $10 \mathrm{IU} / \mathrm{ml}$ penicillin and $100 \mu \mathrm{g} / \mathrm{ml}$ streptomycin (Arterium Corporation, Ukraine). The sedimentation procedure was repeated twice. The resulting cell suspension was used in further work.

Cryogenic vials of $1.8 \mathrm{ml}$ (Nunc, Denmark) were used for cryopreservation. The volume of cell suspension came to $1 \mathrm{ml}$, the cell number in each sample was $5 \times 10^{6}$. The DMSO, HES (MW 200,000 Da), fetal bovine serum (FBS) (Biowest, France), bovine serum albumin (BSA) (Sigma-Aldrich, USA) were applied as cryoprotective compounds. Cryoprotective solutions were prepared on the basis of Ham's / F12 medium.

The composition of the studied cryoprotective media:

1 - Ham's / F12 medium, designated as an additivefree solution, but supplemented with $0 ; 0.7 ; 1.4 ; 2.1$; 2.8 M DMSO;

2 - Ham's / F12 medium with 10\% FBS supplemented with $0 ; 0.7 ; 1.4 ; 2.1 ; 2.8 \mathrm{M} \mathrm{DMSO}$;

3 - Ham's / F12 medium with $5 \mathrm{mg} / \mathrm{ml}$ BSA supplemented with $0 ; 0.7 ; 1.4 ; 2.1 ; 2.8 \mathrm{M}$ DMSO;

4 - Ham's / F12 medium with $50 \mathrm{mg} / \mathrm{ml} \mathrm{HES}$ supplemented with $0 ; 0.7 ; 1.4 ; 2.1 ; 2.8 \mathrm{M} \mathrm{DMSO}$;

5 - Ham's / F12 medium with $100 \mathrm{mg} / \mathrm{ml}$ HES supplemented with $0 ; 0.7 ; 1.4 ; 2.1 ; 2.8 \mathrm{M}$ DMSO.

The samples were cooled using a programmable freezer ZP-10 (Special Designing and Technical Bureau with Experimental Unit at the Institute for Problems of Cryobiology and Cryomedicine of NAS of Ukraine) down to $-80^{\circ} \mathrm{C}$ with $1^{\circ} \mathrm{C} / \mathrm{min}$ rate. They were then kept at $-80^{\circ} \mathrm{C}$ for $15 \mathrm{~min}$ and immersed into liquid nitrogen. The samples were thawed in a water bath at $37^{\circ} \mathrm{C}$ until the crystalline phase disappeared.

The post-thaw cell suspensions were washed from cryoprotective solution by its gradual dilution with Ham's / F12 medium. After dilution, the suspension was centrifuged at $325 \mathrm{~g}$ for $3 \mathrm{~min}$ and the supernatant was removed. Cells were resuspended in Ham's / F12 and then centrifuged again. After washing, a final volume of suspension was brought up to $1 \mathrm{ml}$ with Ham's / F12 medium. 
ведення суспензію центрифугували при $325 \mathrm{~g}$ протягом 3 хв та видаляли супернатант. Клітини ресуспендували у Наm's/F12 та повторно проводили процедуру центрифугування. Після відмивання кінцевий об’єм суспензії доводили до 1 мл середовищем Наm’s/F12.

Життєздатність КІ оцінювали за допомогою барвника трипанового синього («Sigma-Aldrich»), який додавали до клітин у співвідношенні 1:1 (кінцева концентрація 2 мг/мл). Кількість клітин підраховували в камері Горяєва.

Загальну збереженість клітин визначали за формулою:

$$
3=\left(\mathrm{K}_{1} / \mathrm{K}_{2}\right) \times 100 \%
$$

де $\mathrm{K}_{1}$ - загальна кількість клітин після кріоконсервування; $\mathrm{K}_{2}$ - загальна кількість клітин перед кріоконсервуванням.

Збереженість життєздатних клітин визначали за формулою:

$$
3 Ж=\left(K_{1} / K_{2}\right) \times 100 \%,
$$

де $\mathrm{K}_{1}$ - кількість клітин, які не були забарвлені трипановим синім після кріоконсервування; $\mathrm{K}_{2}-$ кількість клітин, які не були забарвлені трипановим синім перед кріоконсервуванням.

Гістохімічне дослідження активності 3 $\beta$-гідроксистероїддегідрогенази (ГСД) проводили за методом, описаним у роботі G. R. Klinefelter та співавт. [20]. Цей фермент є необхідним для синтезу стероїдних гормонів, а отже, може слугувати маркером стероїд-продукуючих клітин сім'яника (клітин Лейдига). Для дослідження 50 мкл клітинної суспензії наносили на предметне скло й висушували щонайменше протягом години за кімнатної температури. Після повного висихання клітини вкривали сумішшю розчинів 1 і 2. Розчин 1 містив 1 мг нітросинього тетразолію, який розчиняли у 0,6 мл розчину дегідроепіандростерону (1 мг/мл) на основі ДМСО. Розчин 2 містив 10 мг $\beta$-нікотинамідаденіндинуклеотиду, який розчиняли у 9,5 мл теплого фосфатно-буферного фізіологічного розчину (PBS). Безпосередньо перед використанням ці два розчини змішували. Клітини забарвлювали протягом двох годин, після чого скло ополіскували водою. Клітини фіксували у $10 \%$-му розчині формаліну у $\mathrm{PBS}$ із 5\%-ю сахарозою протягом хвилини. На клітини наносили суміш гліцерину 3 PBS у співвідношенні $1: 1$, накривали покривним склом і підраховували клітини, які знаходилися у полі зору за допомогою мікроскопа («Olimpus IX 71», США) при збільшенні окуляра $\times 10$ та об'єктива $\times 20, \times 40$ та $\times 60$.
The ICs viability was assessed using trypan blue dye (Sigma-Aldrich), added in 1:1 ratio to the cells ( $2 \mathrm{mg} / \mathrm{ml}$ final concentration). The cell number was counted in Goryaev's chamber.

General cell survival was determined by the following formula:

$$
\mathrm{S}=\left(\mathrm{K}_{1} / \mathrm{K}_{2}\right) \times 100 \% \text {, }
$$

where $\mathrm{K}_{1}$ was the total cell number after cryopreservation, $\mathrm{K}_{2}$ was the total cell number prior to cryopreservation.

Survival of viable cells was determined by the formula:

$$
\mathrm{SV}=\left(\mathrm{K}_{1} / \mathrm{K}_{2}\right) \times 100 \%
$$

where $K_{1}$ was the number of cells, not stained with trypan blue after cryopreservation, $\mathrm{K}_{2}$ was the number of cells, not stained with trypan blue prior to cryopreservation.

The 3 $\beta$-hydroxysteroid dehydrogenase (HSD) activity was histochemically studied using the method described by G.R. Klinefelter et al. [19]. This enzyme is required for steroid hormone synthesis, and therefore can serve as a marker of steroid-producing testicular cells (Leydig cells). For the study, $50 \mu \mathrm{l}$ of cell suspension were applied to a glass slide and dried for at least one hour at room temperature. After complete drying, the cells were covered with a mixture of solutions 1 and 2. Solution 1 included $1 \mathrm{mg}$ of nitroblue tetrazolium, dissolved in $0.6 \mathrm{ml}$ of DMSO-based dehydroepiandrosterone solution (1 mg/ ml). Solution 2 contained $10 \mathrm{mg}$ of $\beta$-nicotinamide adenine dinucleotide, dissolved in $9.5 \mathrm{ml}$ of warm phosphate-buffered saline (PBS). These two solutions were mixed immediately before use. Cells were stained for $2 \mathrm{hrs}$, the glass slides were rinsed with water. Cells were then fixed in a $10 \%$ formalin solution in PBS with 5\% sucrose for 1 minute. Next, they were coated with glycerol and PBS mixture in 1:1 ratio, and covered with glass. Afterwards a number of cells was counted in microscope field of view (Olympus IX 71, USA) with $\times 10$ ocular and $\times 20, \times 40$ and $\times 60$ objective.

The survival of steroid-producing cells $\left(\mathrm{HSD}^{+}-\right.$ cells) was determined by the formula:

$$
\mathrm{SH}=\left(\mathrm{K}_{1} / \mathrm{K}_{2}\right) \times 100 \%
$$

where $\mathrm{K}_{1}$ was the number of cells stained positively after cryopreservation, $\mathrm{K}_{2}$ was the number of cells stained positively before cryopreservation. 
Збереженість стероїд-продукуючих клітин (ГСД+клітин) клітин визначали за формулою:

$$
3 \Gamma=\left(\mathrm{K}_{1} / \mathrm{K}_{2}\right) \times 100 \% \text {, }
$$

де $\mathrm{K}_{1}$ - кількість позитивно забарвлених клітин після кріоконсервування; $\mathrm{K}_{2}$ - кількість позитивно забарвлених клітин перед кріоконсервуванням.

Для визначення метаболічної активності клітин до 500 мкл суспензії КІ додавали 50 мкл розчину 3-(4,5-диметилтіазол-2-іл)-2,5-дифенілтетразолію бромід (5 мг/мл) («Sigma-Aldrich»). Клітини інкубували протягом двох годин при $34^{\circ} \mathrm{C}$. Після цього зразки центрифугували та видаляли супернатант. До осаду додавали 450 мкл ДМСО. Оптичну щільність вимірювали за довжиною хвилі $530 \mathrm{Hм.}$

Збереження метаболічної активності визначали за формулою:

$$
\mathrm{MA}=\left(\mathrm{E}_{1} / \mathrm{E}_{2}\right) \times 100 \%,
$$

де $\mathrm{E}_{1}$ - оптична щільність зразків після кріоконсервування; $\mathrm{E}_{2}$ - оптична щільність зразків перед кріоконсервуванням.

Слід відзначити, що залежність оптичної щільності від кількості клітин у досліджуваному діапазоні мала лінійний характер.

Усі дані на діаграмах представлені як медіана, 25 та 75\%-й процентилі, мінімальне та максимальне значення. Відмінності визначали за критерієм Крускала-Уоліса. Додатково дані ранжували, після чого використовували критерій Ньюмена-Кейлса для множних порівнянь. Усі розрахунки здійснювали за допомогою пакета программ «Statistica 6.0» («StatSoft Inc.», США).

\section{Результати та обговорення}

Результати досліджень показали, що додавання ДМСО значуще збільшувало збереженість КI (рис. 1). Загальна збереженість КІ була дуже низькою без ДМСО, однак максимальна концентрація ДМСО (2,8 М) так само не сприяла збереженості, і навіть зменшувала іiі як із застосуванням розчинів без домішок, так і тих, що містили БСА, ФТС або ГЕК. Ймовірно, у цих випадках ДМСО проявляв свій токсичний ефект. Найбільша загальна збереженість у розчинах без домішок спостерігалася за використання 1,4 М ДМСО - 14,5 (10,8; 18,9)\%. Слід також зазначити, що додавання 10\%-ї ФТС приводило до збільшення загальної збереженості до 28,6 $(23,3 ; 31,3) \%$ у розчині, який містив 1,4 М ДМСО. Найбільший позитивний вплив на загальну збе-
To determine the metabolic activity of cells, $500 \mu \mathrm{l}$ of ICs suspension were supplemented with $50 \mu \mathrm{l}$ of 3-(4,5-dimethylthiazol-2-yl)-2,5-diphenyl tetrazolium bromide solution $(5 \mathrm{mg} / \mathrm{ml})$ (Sigma-Aldrich). Cells were incubated for two hrs at $34^{\circ} \mathrm{C}$. The samples were then centrifuged and the supernatant was removed. The pelleted cells were supplemented with $450 \mu \mathrm{l}$ of DMSO. The optical density was measured at $530 \mathrm{~nm}$ wavelength.

Preservation of metabolic activity was determined by the formula:

$$
\mathrm{NA}=\left(\mathrm{E}_{1} / \mathrm{E}_{2}\right) \times 100 \%
$$

where $E_{1}$ was optical density of the samples after cryopreservation, $\mathrm{E}_{2}$ was optical density of samples before cryopreservation.

Notably, that the dependence of optical density on cell number within the studied range was linear.

All the data in diagrams were presented as median, $25 \%, 75 \%$ percentiles, minimum and maximum value. Differences were determined by the KruskalWallis test. The data were additionally ranked, and the Newman-Keuls test was then used for multiple comparisons. All the calculations were performed using Statistica 6.0 software (StatSoft Inc., USA).

\section{Results and discussion}

Our findings showed the DMSO supplement to increase significantly the ICs survival (Fig. 1). The general ICs survival was very low without DMSO use, but its maximum concentration (2.8 M) hardly promoted survival as well, and even suppressed it when applying the additive-free solutions and those containing BSA, FBS or HES. In these cases DMSO was toxic. The highest general survival in the additive-free solutions was observed when using 1.4 M DMSO and came to 14.5 (10.8; $18.9) \%$. It should be also noted, that $10 \%$ FCS supplement increased the total survival up to 28.6 $(23.3 ; 31.3) \%$ in the $1.4 \mathrm{M}$ DMSO-contained solution. The highest positive effect on general survival, namely $31.5(26.1 ; 39.7) \%$ had the solution, containing $100 \mathrm{mg} / \mathrm{ml}$ HES in combination with 0.7 M DMSO.

Our findings on post-cryo survival of viable cells showed that when using the additive-free solutions their maximum survival was observed in those containing $1.4 \mathrm{M}$, namely $8.8(4.8 ; 12.3) \%$ (Fig. 2). However, an increased survival rate of viable cells was observed in the solutions, that included $10 \%$ FBS and 1.4 M DMSO (20.9 (17.6; 27.0)\%), 

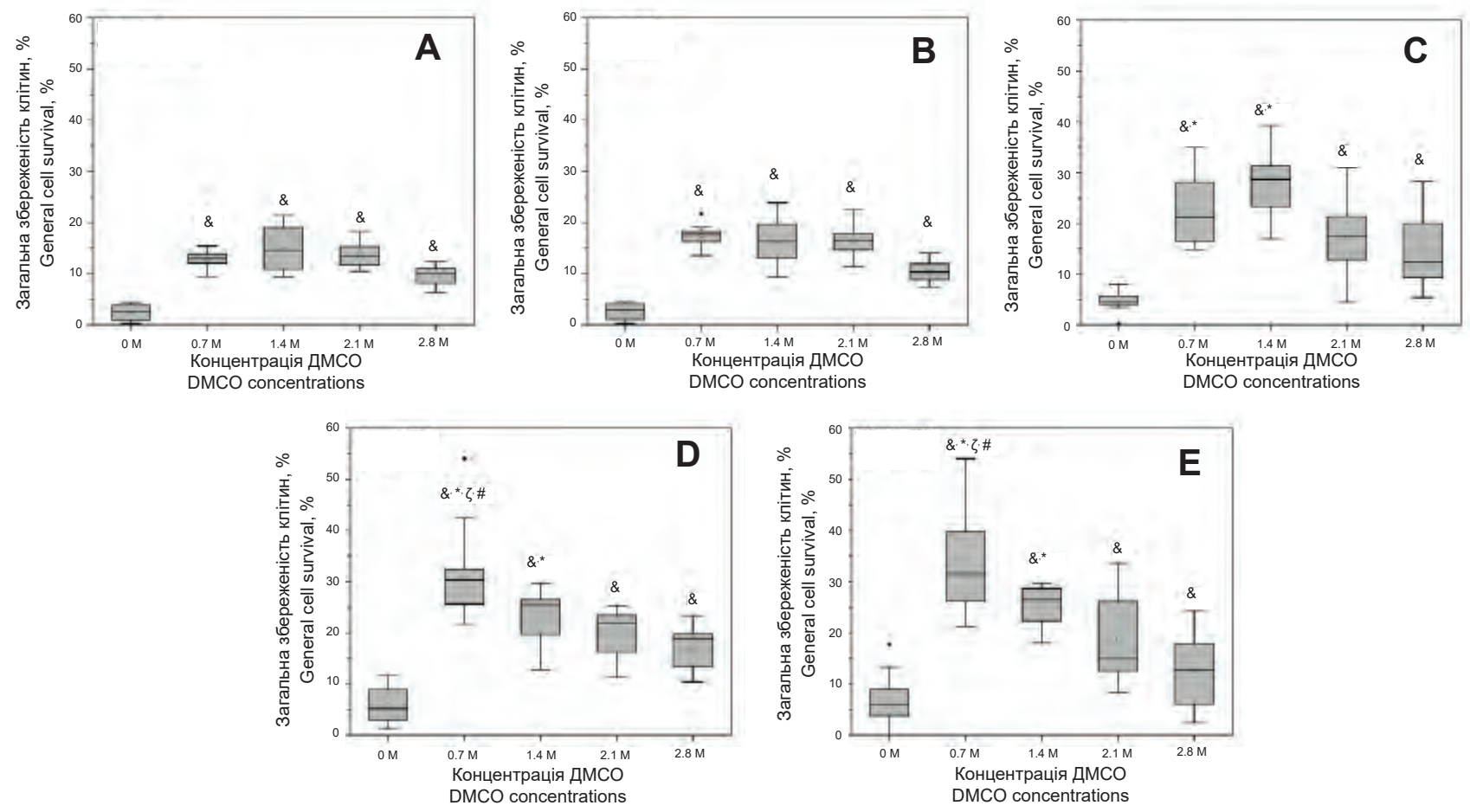

Рис. 1. Загальна збереженість KІ після кріоконсервування у розчинах на основі ДМСО: А - без домішок, В - 5 мг/мл БСА, C - 10\% ФТС, D - 50 мг/мл ГЕК, E - 100 мг/мл ГЕК; \& - розбіжності значущі відносно розчинів без ДМСО; * - розбіжності значущі відносно розчинів із ДМСО без домішок; $\zeta$ - розбіжності значущі відносно розчинів із БСА, які мають однакові концентрації ДМСО; " - розбіжності значущі відносно розчинів із ФТС, які мають однакові концентрації ДМСО; $p \leq 0,05$.

Fig. 1. Post-cryo general survival rate of ICs in DMSO - based solutions: $\mathbf{A}$ - additive-free, $\mathbf{B}-5 \mathrm{mg} / \mathrm{ml}$ BSA, C - $10 \%$ FBS, D - $50 \mathrm{mg} / \mathrm{ml} \mathrm{HES,} \mathrm{E} \mathrm{-} 100 \mathrm{mg} / \mathrm{ml} \mathrm{HES}$; \& - differences were significant with respect to DMSO-free solutions; * differences were significant with respect to additive-free solutions containing DMSO; $\zeta$ - differences were significant with respect to solutions with BSA, having equal DMSO concentrations; \#- differences were significant with respect to solutions with FBS, having equal DMSO concentrations; $p \leq 0.05$.

реженість мав розчин із 100 мг/мл ГЕК у комбінації з 0,7 М ДМСО - 31,5 (26,1; 39,7)\%.

Результати дослідження збереженості життєздатних клітин після кріоконсервування показали, що при використанні розчинів без домішок максимальна збереженість визначалася у розчині з 1,4 М - 8,8 (4,8; 12,3)\% (рис. 2). Проте спостерігали збільшення збереженості життєздатних клітин після використання розчинів, які містили $10 \%$ ФТС та 1,4 М ДМСО $(20,9(17,6 ; 27,0) \%)$, а також розчинів із $50 \mathrm{i} 100 \mathrm{MГ} /$ мл ГЕК та $0,7 \mathrm{M}$ ДМСО - 24,8 $(19,6 ; 29,7) \%$ і 24, $8(21,1 ; 35,8) \%$ відповідно.

Збереженість ГСД від концентрацій ДМСО (рис. 3). Додавання до кріозахисного розчину БСА не збільшувало цей показник. Проте додавання 10\% ФТС або ГЕК, особливо у концентрації 100 мг/мл, значно збільшувало збереженість ГСД-'клітин. Цей показник був найкращим у розчині, який містив 100 мг/мл ГЕК у комбінації з 0,7 М ДМСО - 31,7 (26,4; $37,3) \%$.

В усіх досліджених зразках метаболічна активність була мінімальною за відсутності as well as the ones with 50 and $100 \mathrm{mg} / \mathrm{ml}$ HES and 0.7 M DMSO, $24.8((19.6 ; 29.7) \%$ and 24.8 $(21.1 ; 35.8) \%$, respectively).

The $\mathrm{HSD}^{+}$-cell survival was also dependent on DMSO concentrations (Fig. 3). The addition of BSA to the cryoprotective solution caused no increase of this value. However, the addition of $10 \%$ FBS or HES, especially at $100 \mathrm{mg} / \mathrm{ml}$ concentration significantly augmented the $\mathrm{HSD}^{+}$-cell survival rate. This index was the highest in the solution with $100 \mathrm{mg} / \mathrm{ml}$ HES together with $0.7 \mathrm{M}$ DMSO, and was $31.7(26.4 ; 37.3) \%$.

In all the studied samples, the metabolic activity was minimum under DMSO absence and tended to decrease at $2.8 \mathrm{M}$ DMSO (Fig. 4). The BSA, FBS and HES supplement promoted the preservation of the metabolic activity of ICs. The highest metabolic activity was observed for ICs cryopreserved in the solutions with $0.7 \mathrm{M}$ DMSO in combination with BSA (48.8 (39.3; 59.5)\%), 1.4 and 2.1 M DMSO with $10 \%$ FBS $(42.3(39.3 ; 51.2)$ and 43.0 (34.9; $49.2) \%$, respectively) and $0.7 \mathrm{M}$ DMSO with 50 and $100 \mathrm{mg} / \mathrm{ml} \operatorname{HES}(47.4$ (39.3); 55.2) and 52.6 $(44.5 ; 60.4) \%$, respectively). 
ДМСО та мала тенденцію до зниження при $2,8 \mathrm{M}$ ДМСО (рис. 4). Додавання БСА, ФТС і ГЕК сприяло збереженості метаболічної активності КІ. Найкращі показники метаболічної активності були для KI, кріоконсервованих у розчинах із 0,7 М ДМСО у комбінації з БСА $(48,8(39,3 ; 59,5) \%)$; 1,4 i 2,1 М ДМСО з $10 \%$ ФТС $(42,3(39,3 ; 51,2)$ i $43,0(34,9 ; 49,2) \%$ відповідно) та 0,7 М ДМСО 350 і 100 мг/мЛ ГЕК $(47,4(39,3 ; 55,2)$ і $52,6(44,5$; 60,4)\% відповідно).

Результати використання ксеногенних компонентів (сироватка, сироватковий альбумін) для кріоконсервування матеріалу сім'яників показано у деяких роботах $[4,18,33]$. Швидкість охолод-
The use of xenogenic components (serum, serum albumin) for testes cryopreservation has been reported in some works [2, 16, 33]. J. Tai et al. [33] have studied $1{ }^{\circ} \mathrm{C} / \mathrm{min}$ cooling rate during cryopreservation of steroid-producing cells of rat testes. Proceeding from these data, we used $10 \%$ and $5 \mathrm{mg} / \mathrm{ml}$ concentrations for FBS and $\mathrm{BSA}$, respectively, and $1{ }^{\circ} \mathrm{C} / \mathrm{min}$ cooling rate. Of interest was the fact, that the $2.1 \mathrm{M}$ DMSO concentration was determined by the authors as the most appropriate for steroidogenic cells [2, 33], but here a potential application of lower DMSO concentrations in combination with HES was shown.
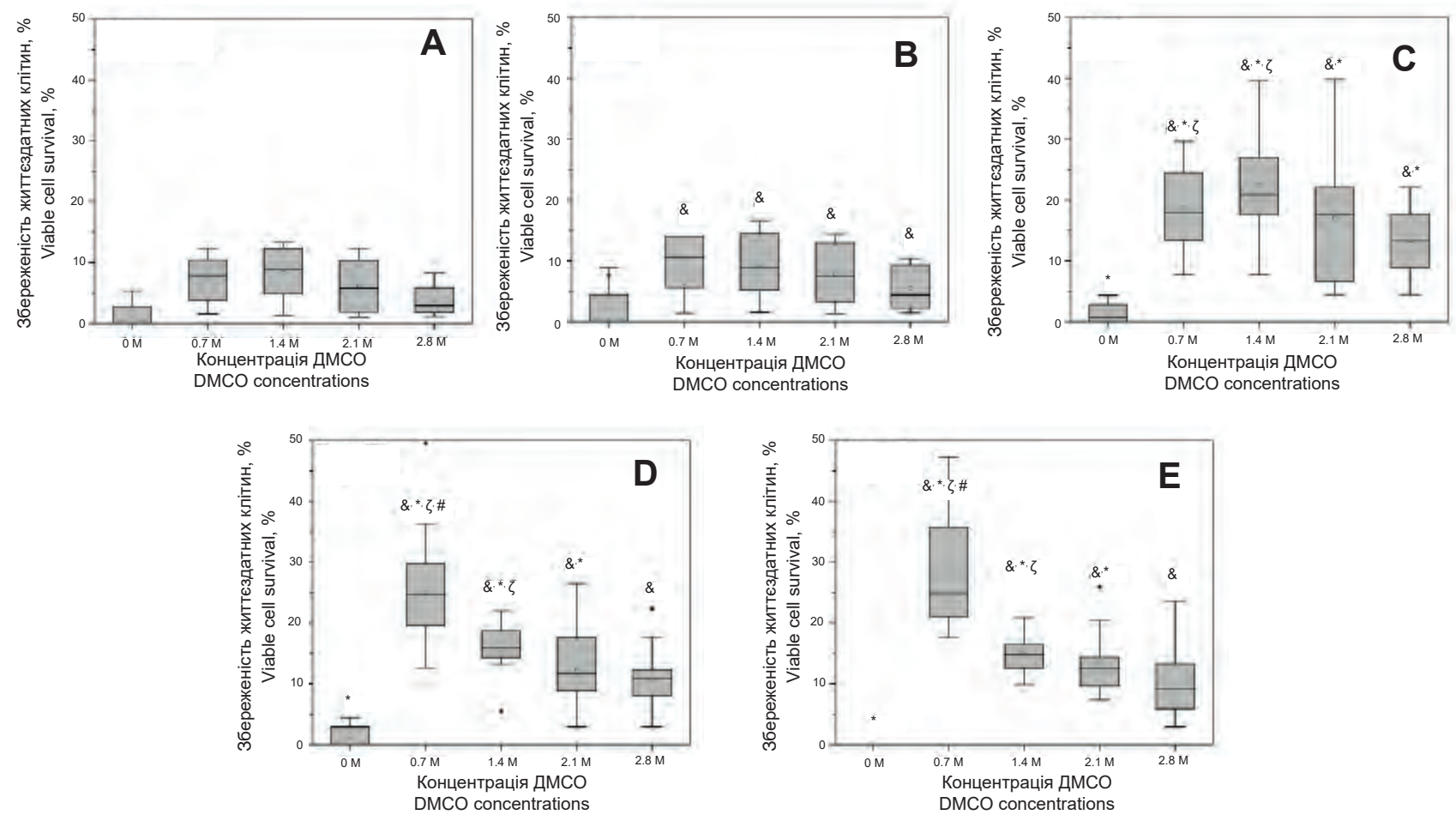

Рис. 2. Збереженість життєздатних КІ після кріоконсервування у розчинах на основі ДМСО: А - без домішок, В 5 мг/мл БСА, C - 10\% ФТС, D - 50 мг/мл ГЕК, E - 100 мг/мл ГЕК; * - розбіжності значущі відносно розчинів із ДМСО без домішок, $\zeta$ - розбіжності значущі відносно розчинів із БСА, які мають однакові концентрації ДМСО; \# - розбіжності значущі відносно розчинів із ФТС, які мають однакові концентрації ДМСО; $p \leq 0,05$.

Fig. 2. Post-cryo survival rate of viable ICs in DMSO - based solutions: $\mathbf{A}$ - additive-free, $\mathbf{B}-5 \mathrm{mg} / \mathrm{ml} B S A, \mathbf{C}-10 \%$ FBS, D - 50 mg / ml HES, E - 100 mg / ml HES; \& - differences were significant in respect to DMSO-free solutions; * - differences were significant in respect to additive-free DMSO solutions, ${ }^{\zeta}$ - differences were significant with respect to solutions with BSA, having equal DMSO concentrations; ${ }^{*}$ - differences were significant with respect to solutions with FBS, having equal DMSO concentrations; $p \leq 0.05$.

ження $1{ }^{\circ} \mathrm{C} / \mathrm{xв}$ при кріоконсервуванні стероїдпродукуючих клітин сім'яників щурів була досліджена у роботі Ј. Таі та співавт. [33]. Відповідно до цих даних ми використовували концентрації ФТС - $10 \%$, БСА - 5 мг/мл та швидкість охолодження $1{ }^{\circ} \mathrm{C} /$ хв. Цікавим $\epsilon$ те, що автори визначають концентрацію ДМСО 2,1 М як найкращу для стероїдогенних клітин $[4,33]$, але у представленій работі показано можливість вико-
The penetrating cryoprotectants (DMSO or glycerol) are known to reduce freezing temperature of cryoprotective solution and to mitigate the effects of high salt concentrations. The salt concentrations can be a threat for cells within the bulk water crystallization temperature range (from negative near-zero temperatures to that of about $-40^{\circ} \mathrm{C}$ ) [32]. In contrast, the cryoprotective properties of HES are associated with its ability to 
ристання нижчих концентрацій ДМСО у комбінації з ГЕК.

Відомо, що проникні кріопротектори (ДМСО або гліцерол) знижують температуру замерзання кріозахисного розчину та нівелюють ефекти високої концентрації солей. Концентрації солей можуть становити загрозу для клітин у діапазоні температур кристалізації основної маси води (від негативних близьконульових температур до температури близько $-40^{\circ} \mathrm{C}$ ) [32]. Навпаки, кріозахисні властивості ГЕК пов'язують absorb water molecules and promote the amorphous phase formation when cooled [20]. Hydroxyethyl starch increases the solution propensity to supercooling and its viscosity, inhibits ice formation, that together allows achieving vitrification state more efficiently [4, 34].

The HES was able to affect the water loss by cell during cooling, promoting their optimal dehydration, and to prevent intracellular ice formation and osmotic stress development [34, 35]. Notably, that HES effect depends on cryo-
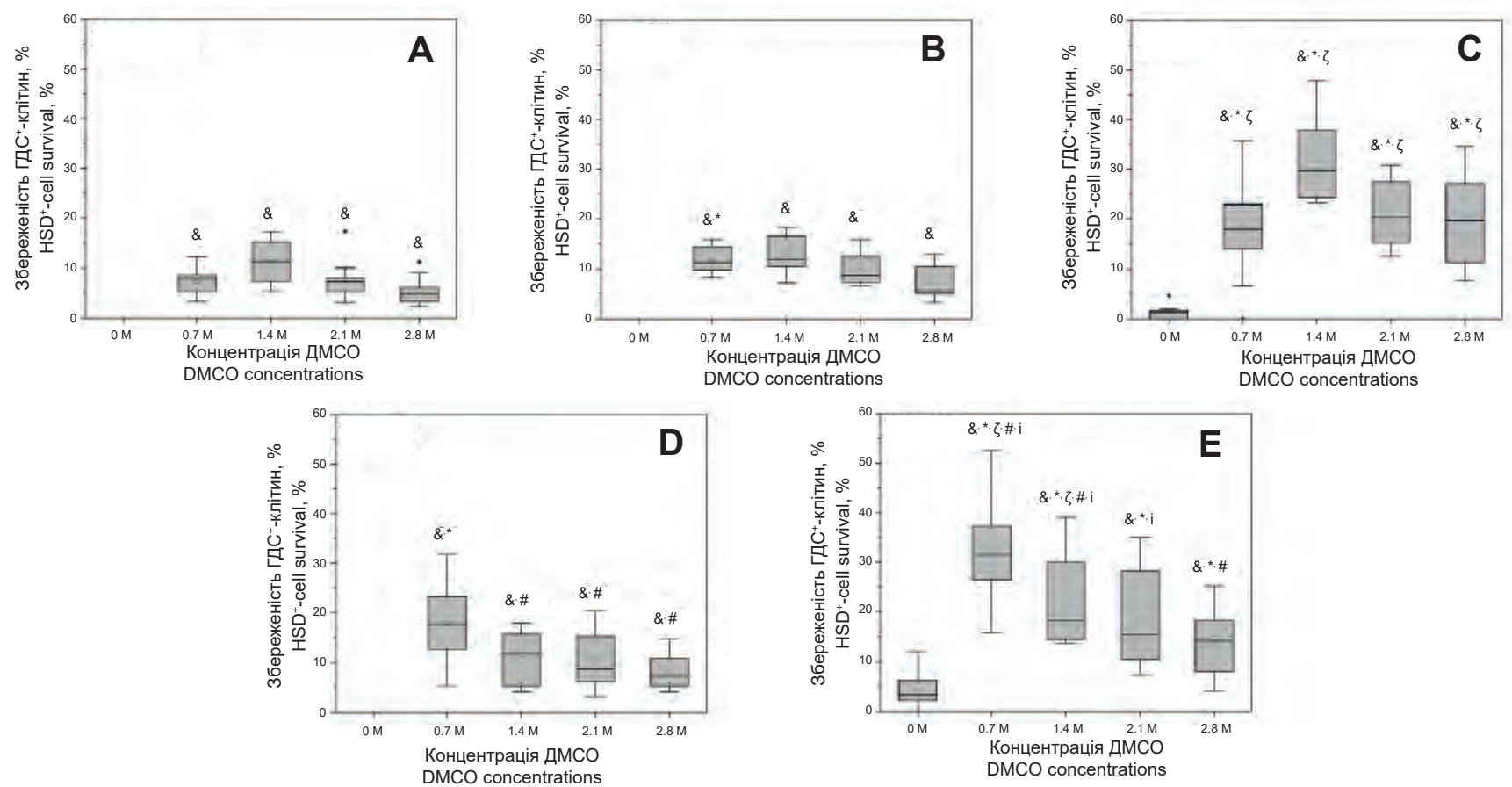

Рис. 3. Збереженість ГСД+-клітин після кріоконсервування у розчинах на основі ДМСО: А - без домішок, В - 5 мг/мл БСА, C - 10\% ФТС, D - 50 мг/мл ГЕК, E - 100 мг/мл ГЕК; \& - розбіжності значущі відносно розчинів без ДМСО; * - розбіжності значущі відносно розчинів без домішок із однаковими концентраціями ДМСО; ‘ - розбіжності значущі відносно розчинів із БСА, які мають однакові концентрації ДМСО; \# - розбіжності значущі відносно розчинів із ФТС, які мають однакові концентрації ДМСО; ' - розбіжності значущі відносно розчинів із 50 мг/мл ГЕК, які мають однакові концентрації ДМСО; $p \leq 0,05$.

Fig. 3. Post-cryo survival rate of $\mathrm{HSD}^{+}$cells in DMSO-based solutions: A - additive-free, B - $5 \mathrm{mg} / \mathrm{ml}$ BSA, C $10 \%$ FBS, D - $50 \mathrm{mg} / \mathrm{ml}$ HES, E - $100 \mathrm{mg} / \mathrm{ml} \mathrm{HES}$; \& - differences were significant with respect to DMSO-free solutions; * - differences were significant with respect to additive-free solutions with equal DMSO concentrations; $\zeta$ - differences were significant with respect to solutions with BSA, having equal DMSO concentrations; \# - differences were significant with respect to solutions with FBS, having the same DMSO concentrations; ${ }^{i}$ - differences were significant with respect to solutions with $50 \mathrm{mg} / \mathrm{ml} \mathrm{HES}$, having equal DMSO concentrations; $p \leq 0.05$.

його здатністю абсорбувати молекули води та при охолоджені сприяти формуванню аморфної фази [21]. Гідроксиетил крохмаль збільшує схильність розчину до переохолодження та його в'язкість, пригнічує формування льоду, що у сукупності дозволяє більш ефективно досягати вітрифікаційного стану [6, 34].

Показано, що ГЕК під час охолодження може впливати на процес дегідратації клітин, сприяючи їх оптимальному зневодненню, запобігати формуванню внутрішньоклітинного льоду та роз- preservation conditions, particularly on its concentration and cooling rate [26].

Many studies, displaying a relative biosafety of HES, have been published. S. Gollub et al. [9] have reported the HES use as a plasma substitute to be safe for humans. Its application as a cryoprotectant for various biological objects in 10-20\% concentrations was described in other studies $[1,15$, $17,27]$. There is a number of researches, where $6-7 \%$ of HES is suggested as substitute for serum proteins in erythrocyte cryopreservation $[22,23]$. We 
витку осмотичного стресу [34, 35]. Важливо зауважити, що дія ГЕК залежить від умов кріоконсервування, особливо від його концентрації та швидкості охолодження [27].

У літературі існує достатня кількість даних, які вказують на відносну біобезпеку ГЕК. У роботі S. Gollub та співавт. [11], показано безпечне для людини використання ГЕК як замінника плазми. У інших роботах описано використання його як кріопротектора для різних біооб'єктів у концентраціях 10-20\% [3, 17, 19, 28]. Існують дослідження, у яких 6-7\% ГЕК розглянуто у якості замінників протеїнів сироватки крові для have also tested similar concentrations of HES: 50 and $100 \mathrm{mg} / \mathrm{ml}$, which can potentially replace the serum protein effect. Previous experiments have shown the HES concentrations below or above of the mentioned are less efficient.

DMSO is known to be able of reducing the cell membrane thickness and of inducing the temporary pore formation even at low concentrations, while causing a complete disintegration of lipid bilayer at high effects [11]. The DMSO use in clinical practice shows a large number of possible side effects (nausea, dizziness, fever) [7, 29]
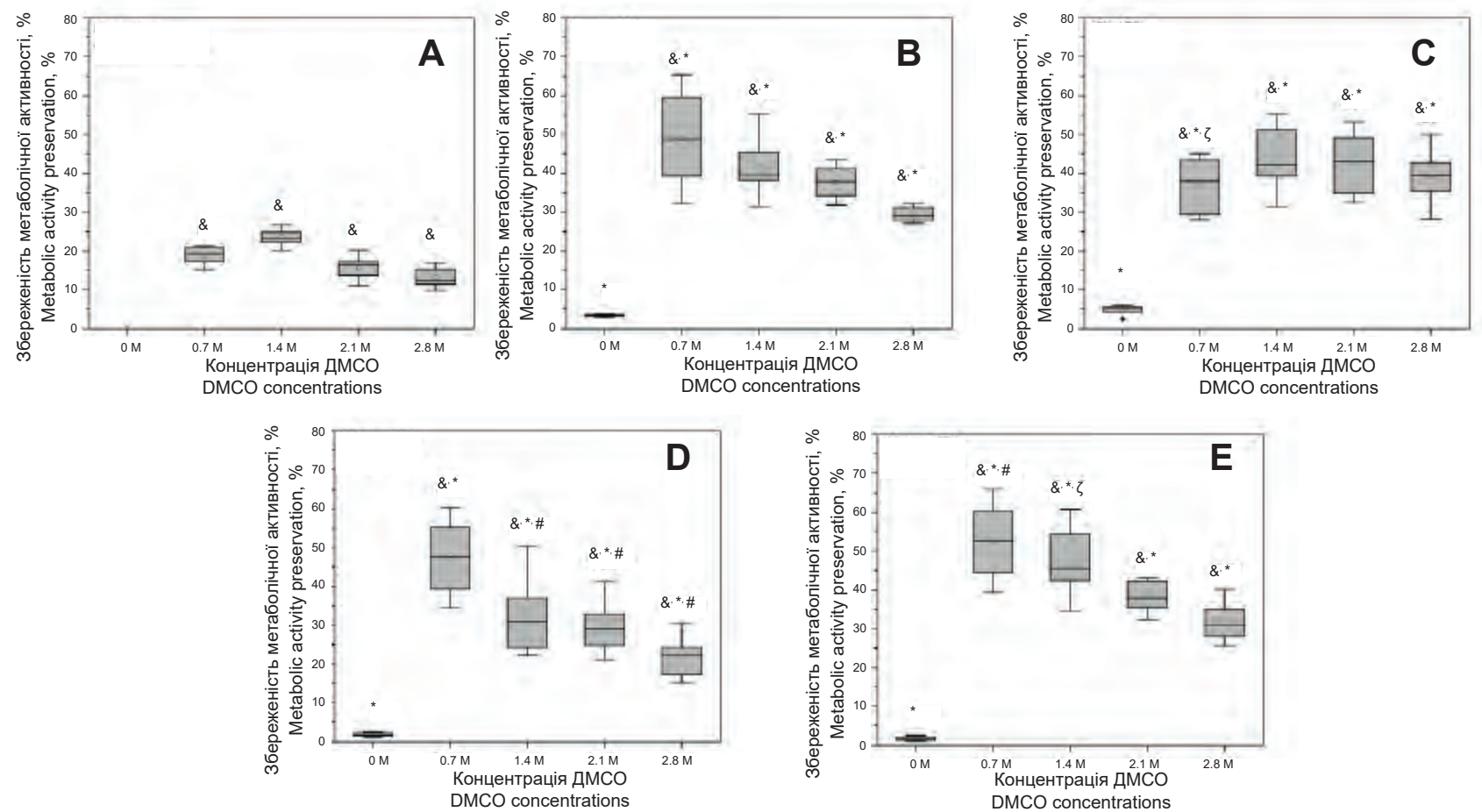

Рис. 4. Збереженість метаболічної активності клітин після кріоконсервування у розчинах на основі ДМСО: A - без домішок, В - 5 мг/мл БСА, C - 10\% ФТС, D - 50 мг/мл ГЕК, E - 100 мг/мл ГЕК; \& - розбіжності значущі відносно розчинів без ДМСО; * - розбіжності значущі відносно розчинів без домішок, які мають однакові концентрації ДМСО; - розбіжності значущі відносно розчинів із БСА, які мають однакові концентрації ДМСО; \# - розбіжності значущі відносно розчинів із ФТС, які мають однакові концентрації ДМСО; $p \leq 0,05$.

Fig. 4. Post-cryo cell metabolic activity preservation in DMSO - based solutions: $\mathbf{A}$ - additive-free, $\mathbf{B}-5 \mathrm{mg} / \mathrm{ml}$ BSA, C - 10\% FBS, D - $50 \mathrm{mg} / \mathrm{ml}$ HES, E - $100 \mathrm{mg} / \mathrm{ml} \mathrm{HES,} \mathrm{\&} \mathrm{-} \mathrm{differences} \mathrm{were} \mathrm{significant} \mathrm{with} \mathrm{respect} \mathrm{to} \mathrm{DMSO-}$ free solutions; * - differences were significant with respect to additive-free solutions, having equal DMSO concentrations; $\zeta$ - differences were significant with respect to solutions with BSA, having equal DMSO concentrations; \# - differences were significant with respect to solutions with FBS, having equal DMSO concentrations; $p \leq 0.05$.

кріоконсервування еритроцитів [23, 24]. Нами також випробувано схожі концентрації ГЕК 50 та 100 мг/мл, які потенційно можуть заміщувати дію протеїнів сироватки. Попередні експерименти показали, що концентрації ГЕК нижче або вище вказаних були менш ефективними.

Відомо, що ДМСО навіть у низьких концентраціях може зменшувати товщину мембрани клітин та індукувати формування тимчасових and neurotoxic (encephalopathy) influences [3]. Therefore, a decrease in DMSO concentration in cryoprotective medium and the elimination of serum components reduce a negative impact of the cryoprotective medium. Notably, that a lower DMSO concentration, than demonstrated by G.R. Ghen et al. [33] and J. Tai et al. [2], i. e. $0.7 \mathrm{M}$ can be applied when using $\mathrm{HES}$ for $\mathrm{HSD}^{+}$-cell cryopreservation. 
пор, а у великих - призводити до повної дезінтеграції ліпідного бішару [13]. При використанні ДМСО у клінічній практиці описано велику кількість можливих побічних (нудота, запаморочення, гарячка) $[9,29]$ та нейротоксичних (енцефалопатія) [5] ефектів. Тому зменшення концентрації ДМСО у кріозахисному середовищі та виключення компонентів сироватки знижують негативну дію кріозахисного середовища. Цікаво, що ГЕК дає можливість застосовувати нижчі концентрації ДМСО - 0,7 М, ніж показано у роботах G.R. Ghen та співавт. [33] та J. Таі та співавт. [4].

\section{Висновки}

1. Додавання ГЕК до складу кріозахисного середовища сприяло збільшенню показників загальної збереженості та підвищенню життєздатних клітин інтерстицію сім'яника порівняно 3 середовищами, які містили БСА або ФТС.

2. Застосування розчину, який містить 100 мг/мЛ ГЕК і 0,7 М ДМСО, дозволило отримати найбільшу збереженість життєздатних КІ сім'яників $(24,8(21,1 ; 35,8) \%)$, та ГСД ${ }^{+}$-клітин $(31,7(26,4$; $37,3) \%$ ), що, в свою чергу, є обгрунтуванням для зниження концентрації ДМСО у кріозахисному розчині з 2,1 до $0,7 \mathrm{M}$.

3. Використання 100 мг/мл ГЕК у комбінації з 0,7 М ДМСО дозволило зберегти метаболічну активність КІ на високому рівні $(52,6(44,5 ; 60,4) \%)$.

Дослідження було проведено в рамках теми 2.2.6.104 «Властивості кріоконсервованих первинних культур клітин ендокринних залоз неонатальних тварин іn vitro ma in vivo при трансплантащіï».

\section{Література}

1. Кирпатовский ВИ, Ефремов ГД, Фролова ЕВ, Кудрявцева лВ. Стимуляция сперматогенеза и синтеза тестостерона путем аллотрансплантации неонатальной тестикулярной ткани под белочную оболочку крипторхированного яичка. Бюллетень экспериментальной биологии и медицины. 2018;166(10):495-501.

2. Петренко ЮА. Криоконсервирование клеток эмбриональной печени человека с использованием ДМСО и высокомолекулярных соединений. Проблемы криобиологии. 2003(3):80-7.

3. Ashwoodsmith M, Warby C, Connor K, Becker G. Lowtemperature preservation of mammalian-cells in tissue culture with polyvinylpyrrolidone (PVP), dextrans, and hydroxyethyl starch (HES). Cryobiology. 1972;9(5):441-9.

\section{Conclusions}

1. The HES addition o cryoprotective medium ensured an increase in general survival rate and that of viable testicular interstitial cells as compared to the BSA or FBS-containing media.

2. The use of the solution, containing $100 \mathrm{mg} /$ $\mathrm{ml}$ HES and $0.7 \mathrm{M}$ DMSO, enabled obtaining the highest survival rate of testicular ICs (24.8 (21.1; $35.8) \%$ ), and $\mathrm{HSD}^{+}$-cells (31.7 (26.4; 37.3)\%), which, in turn, substantiated the reduction of DMSO concentration in cryoprotective solution from 2.1 to $0.7 \mathrm{M}$.

3. The use of $100 \mathrm{mg} / \mathrm{ml}$ HES in combination with $0.7 \mathrm{M}$ DMSO allowed the preservation of metabolic activity of ICs at a high level (52.6 (44.5; $60.4) \%$ ).

The study was carried out within the project 2.2.6.104 'Properties of Cryopreserved Primary Cell Cultures of Neonatal Animal Endocrine Glands In Vitro and In Vivo During Transplantation'.

\section{References}

1. Ashwoodsmith M, Warby C, Connor K, Becker G. Lowtemperature preservation of mammalian-cells in tissue culture with polyvinylpyrrolidone (PVP), dextrans, and hydroxyethyl starch (HES). Cryobiology. 1972;9(5):441-9.

2. Chen GR, Ge RS, Lin H, et al. Development of a cryopreservation protocol for Leydig cells. Hum Reprod. 2007;22(8):2160-8.

3. Chen-Plotkin AS, Vossel KA, Samuels MA, Chen MH. Encephalopathy, stroke, and myocardial infarction with DMSO use in stem cell transplantation. Neurology. 2007;68(11):85961.

4. Connor W, Ashwood-Smith MJ. Cryoprotection of mammalian cells in tissue culture with polymers; possible mechanisms. Cryobiology. 1973;10(6):488-96.

5. Dokras A, Sargent IL, Redman CW, Barlow DH. Sera from women with unexplained infertility inhibit both mouse and human embryo growth in vitro. Fertil Steril. 1993;60(2):285-92.

6. Dyrlund TF, Kirkegaard K, Poulsen ET, et al. Unconditioned commercial embryo culture media contain a large variety of non-declared proteins: a comprehensive proteomics analysis. Hum Reprod. 2014;29(11):2421-30.

7. Ferrucci PF, Martinoni A, Cocorocchio E, et al. Evaluation of acute toxicities associated with autologous peripheral blood progenitor cell reinfusion in patients undergoing high-dose chemotherapy. Bone Marrow Transplant. 2000;25(2):173-7.

8. Gao X, Chang XB, Wu RY, Zhan BY. Allotransplantation of cryopreserved human Leydig cells. Transplant Proc. 1994;26(6):3490.

9. Gollub S, Schechter DC, Hirose T, Bailey CP. Use of hydroxyethyl starch solution in extensive surgical operations. Surg Gynecol Obstet. 1969;128(4):725-8.

10.Graham JE, Meola DM, Kini NR, Hoffman AM. Comparison of the effects of glycerol, dimethyl sulfoxide, and hydroxyethyl starch solutions for cryopreservation of avian red blood cells. Am J Vet Res. 2015;76(6):487-93.

11. GurtovenkoAA, Anwar J. Modulating the structure and properties of cell membranes: the molecular mechanism of action of dimethyl sulfoxide. J Phys Chem B. 2007;111(35):10453-60. 
4. Chen GR, Ge RS, Lin H, et al. Development of a cryopreservation protocol for Leydig cells. Hum Reprod. 2007;22 (8):2160-8.

5. Chen-Plotkin AS, Vossel KA, Samuels MA, Chen $M H$ Encephalopathy, stroke, and myocardial infarction with DMSO use in stem cell transplantation. Neurology. 2007;68 (11):859-61.

6. Connor W, Ashwood-Smith MJ. Cryoprotection of mammalian cells in tissue culture with polymers; possible mechanisms. Cryobiology. 1973;10(6):488-96.

7. Dokras A, Sargent IL, Redman CW, Barlow DH. Sera from women with unexplained infertility inhibit both mouse and human embryo growth in vitro. Fertil Steril. 1993;60(2):285-92.

8. Dyrlund TF, Kirkegaard K, Poulsen ET, et al. Unconditioned commercial embryo culture media contain a large variety of non-declared proteins: a comprehensive proteomics analysis. Hum Reprod. 2014;29(11):2421-30.

9. Ferrucci PF, Martinoni A, Cocorocchio E, et al. Evaluation of acute toxicities associated with autologous peripheral blood progenitor cell reinfusion in patients undergoing high-dose chemotherapy. Bone Marrow Transplant. 2000;25(2):173-7.

10.Gao X, Chang XB, Wu RY, Zhan BY. Allotransplantation of cryopreserved human Leydig cells. Transplant Proc. 1994;26(6):3490.

11. Gollub S, Schechter DC, Hirose T, Bailey CP. Use of hydroxyethy starch solution in extensive surgical operations. Surg Gyneco Obstet. 1969;128(4):725-8.

12. Graham JE, Meola DM, Kini NR, Hoffman AM. Comparison of the effects of glycerol, dimethyl sulfoxide, and hydroxyethy starch solutions for cryopreservation of avian red blood cells Am J Vet Res. 2015;76(6):487-93

13. Gurtovenko AA, Anwar J. Modulating the structure and properties of cell membranes: the molecular mechanism of action of dimethyl sulfoxide. J Phys Chem B. 2007;111(35):10453-60.

14. Hinckley GT, Johnson CJ, Jacobson KH, et al. Persistence of pathogenic prion protein during simulated wastewater treatment processes. Environ Sci Technol. 2008;42(14):5254-9.

15. Imaizumi K, Nishishita N, Muramatsu M, et al. A simple and highly effective method for slow-freezing human pluripotent stem cells using dimethyl sulfoxide, hydroxyethyl starch and ethylene glycol. PLoS One. 2014[Cited 13.03.2020];9(2): e88696.Availabel from: //https://journals.plos.org/plosone/ article?id=10.1371/journal.pone.0088696

16.Kemmann E. Creutzfeldt-Jakob disease (CJD) and assisted reproductive technology (ART). Quantification of risks as part of informed consent. Hum Reprod. 1998;13(7):1777.

17.Kenmochi T, Asano T, Maruyama M, et al. Cryopreservation of human pancreatic islets from non-heart-beating donors using hydroxyethyl starch and dimethyl sulfoxide as cryoprotectants. Cell Transplant. 2008;17(1-2):61-7.

18.Keros V, Hultenby K, Borgström B, et al. Methods of cryopreservation of testicular tissue with viable spermatogonia in pre-pubertal boys undergoing gonadotoxic cancer treatment. Hum Reprod. 2007;22(5):1384-95.

19. Kim H, Tanaka S, Une S, et al. A comparative study of the effects of glycerol and hydroxyethyl starch in canine red blood cell cryopreservation. J Vet Med Sci. 2004;66(12):1543-7.

20.Klinefelter GR, Hall PF, Ewing LL. Effect of luteinizing hormone deprivation in situ on steroidogenesis of rat Leydig cells purified by a multistep procedure. Biol Reprod. 1987;36(3):769-83.

21.Körber C, Scheiwe MW. The cryoprotective properties of hydroxyethyl starch investigated by means of differential thermal analysis. Cryobiology. 1980;17(1):54-65.

22.Leung PC, Gronow MJ, Kellow GN, et al. Serum supplement in human in vitro fertilization and embryo development. Fertil Steril. 1984;41(1):36-9.

23. Lionetti FJ, Hunt SM, Mattaliano RJ, Valeri CR. In vitro studies of cryopreserved baboon granulocytes. Transfusion. 1978;18(6):685-92.
12. Hinckley GT, Johnson CJ, Jacobson KH, et al. Persistence of pathogenic prion protein during simulated wastewater treatment processes. Environ Sci Technol. 2008;42(14):5254-9.

13.Imaizumi $\mathrm{K}$, Nishishita $\mathrm{N}$, Muramatsu $\mathrm{M}$, et al. A simple and highly effective method for slow-freezing human pluripotent stem cells using dimethyl sulfoxide, hydroxyethyl starch and ethylene glycol. PLoS One [Internet]. 2014 Feb 12 [cited 2020 March 13];9(2):e88696.Available from: //https://journals.plos. org/plosone/article?id=10.1371/journal.pone.0088696

14.Kemmann E. Creutzfeldt-Jakob disease (CJD) and assisted reproductive technology (ART). Quantification of risks as part of informed consent. Hum Reprod. 1998;13(7):1777.

15.Kenmochi T, Asano T, Maruyama M, et al. Cryopreservation of human pancreatic islets from non-heart-beating donors using hydroxyethyl starch and dimethyl sulfoxide as cryoprotectants. Cell Transplant. 2008;17(1-2):61-7.

16.Keros V, Hultenby K, Borgström B, et al. Methods of cryopreservation of testicular tissue with viable spermatogonia in pre-pubertal boys undergoing gonadotoxic cancer treatment. Hum Reprod. 2007;22(5):1384-95.

17.Kim H, Tanaka S, Une S, et al. A comparative study of the effects of glycerol and hydroxyethyl starch in canine red blood cell cryopreservation. J Vet Med Sci. 2004;66(12):1543-7.

18. Kirpatovskii VI, Efremov GD, Frolova EV, Kudryavtseva LV. Stimulation of spermatogenesis and synthesis of testosterone by allotransplantation of neonatal testicular tissue under tunica albuginea of cryptorchid testis. Bull Exp Biol Med. 2019;166(4):497-502.

19. Klinefelter GR, Hall PF, Ewing LL. Effect of luteinizing hormone deprivation in situ on steroidogenesis of rat Leydig cells purified by a multistep procedure. Biol Reprod. 1987;36(3):769-83.

20.Körber C, Scheiwe MW. The cryoprotective properties of hydroxyethyl starch investigated by means of differential thermal analysis. Cryobiology. 1980;17(1):54-65

21.Leung PC, Gronow MJ, Kellow GN, et al. Serum supplement in human in vitro fertilization and embryo development. Fertil Steril. 1984;41(1):36-9.

22. Lionetti FJ, Hunt SM, Mattaliano RJ, Valeri CR. In vitro studies of cryopreserved baboon granulocytes. Transfusion. 1978;18(6):685-92.

23.Lionetti FJ, Hunt SM. Cryopreservation of human red cells in liquid nitrogen with hydroxyethyl starch. Cryobiology. 1975;12(2):110-8.

24. Liu $\mathrm{Y}$, Xu X, Ma X, et al. Cryopreservation of human bone marrow-derived mesenchymal stem cells with reduced dimethylsulfoxide and well-defined freezing solutions. Biotechnol Prog. 2010;26(6):1635-43.

25. Liu Y, Xu X, Ma XH, et al. Effect of various freezing solutions on cryopreservation of mesenchymal stem cells from different animal species. Cryo Letters. 2011;32(5):425-35.

26.McGann LE. Differing actions of penetrating and nonpenetrating cryoprotective agents. Cryobiology. 1978;15(4):38290.

27.Persidsky M, Ellett M. Hydroxyethyl starch as a cryopreservative for nucleated mammalian-cells. Cryobiology. 1971;8(6):586-7.

28. Petrenko Y. Cryopreservation of human embryonic liver cells using DMSO and high molecular weight polymers. Problems of Cryobiology. 2003; (3):80-7.

29.Sánchez-Salinas A, Cabañas-Perianes V, Blanquer M, et al. An automatic wash method for dimethyl sulfoxide removal in autologous hematopoietic stem cell transplantation decreases the adverse effects related to infusion. Transfusion. 2012;52(11):2382-6.

30.Scheinkönig C, Kappicht S, Kolb HJ, Schleuning M. Adoption of long-term cultures to evaluate the cryoprotective potential of trehalose for freezing hematopoietic stem cells. Bone Marrow Transplant. 2004;34(6):531-6.

31.Snyman E, Van der Merwe JV. Endotoxin-polluted medium in a human in vitro fertilization program. Fertil Steril. 1986;46(2):273_ 6. 
24.Lionetti FJ, Hunt SM. Cryopreservation of human red cells in liquid nitrogen with hydroxyethyl starch. Cryobiology. 1975;12(2):110-8.

25. Liu Y, Xu X, Ma X, et al. Cryopreservation of human bone marrow-derived mesenchymal stem cells with reduced dimethylsulfoxide and well-defined freezing solutions. Biotechnol Prog. 2010;26(6):1635-43.

26. Liu Y, Xu X, Ma XH, et al. Effect of various freezing solutions on cryopreservation of mesenchymal stem cells from different animal species. CryoLetters. 2011;32(5):425-35.

27.McGann LE. Differing actions of penetrating and nonpenetrating cryoprotective agents. Cryobiology. 1978;15(4):382-90.

28.Persidsky M, Ellett M. Hydroxyethyl starch as a cryopreservative for nucleated mammalian cells. Cryobiology. 1971;8(6):586-7.

29.Sánchez-Salinas A, Cabañas-Perianes V, Blanquer $M$, et al An automatic wash method for dimethyl sulfoxide removal in autologous hematopoietic stem cell transplantation decreases the adverse effects related to infusion. Transfusion. 2012;52(11):2382-6.

30.Scheinkönig C, Kappicht S, Kolb HJ, Schleuning M. Adoption of long-term cultures to evaluate the cryoprotective potential of trehalose for freezing hematopoietic stem cells. Bone Marrow Transplant. 2004;34(6):531-6.

31.Snyman E, Van der Merwe JV. Endotoxin-polluted medium in a human in vitro fertilization program. Fertil Steril. 1986;46(2):2736.

32.Stolzing A, Naaldijk Y, Fedorova V, Sethe S. Hydroxyethylstarch in cryopreservation - mechanisms, benefits and problems. Transfus Apher Sci. 2012;46(2):137-47.

33. Tai J, Tze WJ, Johnson HW. Cryopreservation of rat Leydig cells for in-vitro and in-vivo studies. Hormone and Metabolic Research. 1994;26(3):145-7.

34.Takahashi T, Hirsh A, Erbe E, Williams RJ. Mechanism of cryoprotection by extracellular polymeric solutes. Biophys J. 1988;54(3):509-18.

35. Thomas MJ, Parry ES, Nash SG, Bell SH. A method for the cryopreservation of red blood cells using hydroxyethyl starch as a cryoprotectant. Transfus Sci. 1996;17(3):385-96.

36. Truyen U, Parrish CR, Harder TC, Kaaden OR. There is nothing permanent except change. The emergence of new virus diseases. Vet Microbiol. 1995;43(2-3):103-22.

37.van Os HC, Drogendijk AC, Fetter WP, et al. The influence of contamination of culture medium with hepatitis $B$ virus on the outcome of in vitro fertilization pregnancies. Am J Obstet Gynecol. 1991;165(1):152-9.
32.Stolzing A, Naaldijk Y, Fedorova V, Sethe S. Hydroxyethylstarch in cryopreservation - mechanisms, benefits and problems. Transfus Apher Sci. 2012;46(2):137-47.

33. Tai J, Tze WJ, Johnson HW. Cryopreservation of rat Leydig cells for in-vitro and in-vivo studies. Hormone and Metabolic Research. 1994;26(3):145-7.

34. Takahashi T, Hirsh A, Erbe E, Williams RJ. Mechanism of cryoprotection by extracellular polymeric solutes. Biophys J. 1988;54(3):509-18.

35. Thomas MJ, Parry ES, Nash SG, Bell SH. A method for the cryopreservation of red blood cells using hydroxyethyl starch as a cryoprotectant. Transfus Sci. 1996;17(3):385-96.

36. Truyen U, Parrish CR, Harder TC, Kaaden OR. There is nothing permanent except change. The emergence of new virus diseases. Vet Microbiol. 1995;43(2-3):103-22.

37.van Os HC, Drogendijk AC, Fetter WP, et al. The influence of contamination of culture medium with hepatitis $B$ virus on the outcome of in vitro fertilization pregnancies. Am J Obstet Gynecol. 1991;165(1):152-9. 